\title{
INTRODUCTION
}

\section{Governing under Constraint}

\author{
Maurizio Carbone and Simona Piattoni
}

The main events of 2015 were undoubtedly international ones. The reactions to the terrorist attacks, mass migrations, economic crisis, and environmental problems may lead the reader to think that Italy has been a "policy-taker" rather than a "policy-maker." And yet a careful analysis of the events of the year suggest that the government led by Matteo Renzi engaged in a series of reforms that were deemed necessary in order to remedy some of the long-standing issues that have caused the national debt to skyrocket and Italy to lose credibility and prestige internationally (Calise 2015a; Salvati 2015c). It is obviously possible to hold very different opinions on the content, mode, and potential results of these reforms; however, we must acknowledge that the government, despite a slim and fractious parliamentary majority, has managed to impose its political agenda. This remarkable decisionmaking drive on the domestic front-which some have branded as "announcism" if not outright "populism" (Pasquino 2015; Revelli 2015; Ventura 2015a) - stands in stark contrast with the hiatus that emerged between statements and actions in international matters, a gap that has had negative effects (Carbone 2015; Colombo and Magri 2016).

This introduction aims to offer an interpretation that is necessarily provisional, given that the ultimate consequences of many policy decisions will be visible only in the future, not only of the policy measures implemented by the Renzi government during the year 2015, but also of the context within which they were made. In order to provide a 
first assessment of these policy decisions, it is necessary to highlight two types of constraints: an internal constraint, due to the difficulty in fashioning ideologically cohesive parliamentary majorities, and an external one, exerted by the growing Europeanization of national political systems and by the pressures deriving from the troubled geopolitical context and the various crises engendered by it. Availing ourselves of the detailed analyses contained in the chapters that make up this edited volume, we try to understand to what extent the Renzi government has shown forward vision, even as its methods and goals remain debatable, or whether it has merely produced empty wishful thinking, particularly in international matters, where Italy by now suffers from a chronic incapacity to free itself from the tutelage of other countries and to play an active role.

\section{A Changing Domestic Political Landscape}

In order to interpret the evolution of the Italian political system in 2015, we should start with three main facts: the election of the president of the Republic, Sergio Mattarella, which changed the relationship between the majority and the opposition; the elections in seven regions, which confirmed the consolidation of the tripolar system and revealed a growing disconnect between the central and the peripheral party systems; and the adoption of a series of institutional reforms that, by strengthening the executive, may lead to the inauguration of the Third (phase of the) Republic. These events help to explain the evolution of the main political parties-an evolution that, one way or another, hinges on the "leadership question": the challenge by Matteo Salvini, party secretary of a growing Northern League (LN), to Silvio Berlusconi, the declining leader of Forza Italia (FI), within the center-right camp; the new turn within the Five Star Movement (M5S), whose charismatic leader Beppe Grillo took a "step back"; and the tensions within the Democratic Party (PD) regarding Renzi's dual role of party secretary and prime minister.

The resignation in January of the president of the Republic, Giorgio Napolitano, at the end of the Italian semester of the EU rotating presidency (July-December 2014), seemed the prelude to a quick election of a new president, thanks to the Nazarene pact between Renzi and Berlusconi that had been sealed the year before. ${ }^{1}$ Faced with virtually irreconcilable goals-preserving the privileged relationship with the center-right in view of a consensual approval of the constitutional reforms, selecting a not too "bulky" personality for the post of president, and keeping together as much as possible his own party-Renzi 
decided to accelerate the election by proposing a candidate who would be sure to meet the approval of the internal PD minority but who had not been approved beforehand by the other parties. Certainly, Mattarella was not Renzi's first choice, but once he realized that he would not be able to have another, more preferred candidate elected, he trusted that Berlusconi would eventually align himself with that decision. Moreover, at least initially, Renzi seemed to have united his own party, whereas Pier Luigi Bersani, the former secretary of the PD, had failed two years earlier to achieve as much on the occasion of the unprecedented re-election of Napolitano. Yet the immediate consequences of the break-up of the Nazarene pact were different from what had been expected (D'Alimonte 2015d). On the one hand, it contributed to sharpening the difficulties that already existed within FI, so much so that a number of deputies left the party, some of them ending up reinforcing the governmental majority. On the other hand, harmony within the PD was short-lived, and divisions between the Renzi secretariat and the party minority resurfaced on a number of occasions. Thus, the executive had to rely on different majorities, depending on which reform was being discussed and voted on. Taking a longer-term view, the personal qualities of Mattarella-his moral integrity and his significant political experience-may, according to Mark Donovan (this volume), play an important role in preserving national cohesion in case of political instability.

As is apparent also from the tables assembled by Valentina Sartori in the appendix, the May regional elections saw the center-left bloc prevail in five regions and the center-right bloc in two of them. Above and beyond this easily foreseeable result-taking into account the fact that a united center-right coalition is wholly capable of beating a fractured center-left coalition (as happened in Liguria) and that the Northern League is especially rooted in the north of the country (hence, the clear victory of the LN candidate in Veneto) - two additional aspects are worth mentioning. First, as noted by Silvia Bolgherini and Selena Grimaldi (this volume), it is evident not only that both party leaderships failed to control the regional secretariats, but also that the Italian political system is by now structured around three poles. In fact, the M5S has become the second or third party in all regions, drawing its strength from the general voters' disenchantment with the parties of the center-right and the tensions existing within the PD, as well as from the competition from more or less radical leftist parties in almost all regions. The second aspect concerns the high abstention rates that were registered particularly in the "red regions." Even though these rates do not warrant concern for a "disabled democracy," abstention cannot be treated as a secondary issue, which Renzi did, incurring, for 
this reason, many criticisms (Ainis 2015b). The variation in abstention rates across elections of different kinds, however, shows that this is not just a question of apathy or the consequence of party decline or of the weakening of ideologies. Rather, it has become a way of sanctioning the behavior of the political class-in this case, the regional political class (D’Alimonte 2015a).

Institutional reforms catalyzed the attention of the political parties for most of the year. First, there was the final adoption of a new electoral law, called "Italicum," which is essentially a proportional system with a majority bonus. As intended by its proponents, this is meant to ensure both governability, thanks to the fact that the bonus is given to the list that reaches a fairly high threshold or that wins in the second round, and representativeness, by guaranteeing a sufficient number of seats to all party lists that reach a threshold, which varies according to whether or not they are members of a coalition (D'Alimonte 2015c). Critical voices were raised against both the excessive size of the majority bonus and the excessive power entrusted to parties' secretariats, which will manage to have nominees of their choice elected given the fairly high number of seats allocated according to partially fixed lists (Pasquino 2015). Second, the reform of the second part of the Italian Constitution-which was approved at its first reading in 2015 and which, after a second positive vote in both branches of Parliament foreseeably in the first months of 2016, will then be put to a national referendum in the fall of 2016-introduces substantial changes to the institutional architecture of the country.

The most significant changes concern the overcoming of "redundant bicameralism" and the introduction of "differentiated bicameralism." Parliament will still have two chambers, but these will have a different composition and functions: the Senate will become a regional representative chamber with curtailed legislative functions, while the Chamber of Deputies will be entrusted with full legislative functions and with voting the executive in or out of office. Other important novelties concern the reform of Title $\mathrm{V}$ of the Constitution, which completely upsets the allocation of legislative competences between the central government and regional governments, eliminates any constitutional reference to the provinces, and gets rid of the National Council on the Economy and Labor (CNEL). Above and beyond the many polemical statements and the inter-party tensions that characterized the approval of this constitutional reform, the final objectives appear to be political stability and the strengthening of the executive. However, if "de facto monocameralism and the second round to identify a winner of the elections are two fundamental elements for any executive that, at least on paper, wants to last and to govern ... for an entire legislature" (Calise 
2015a: 207), mere stability does not necessarily guarantee effective government (Pasquino 2015).

As far as the party system is concerned, the center-right, as Francesco Raniolo (this volume) explains, experienced a year-long destructuring period. On the one hand, we witnessed the steady decline of Berlusconi, who gradually lost control over his own party (as increasing numbers of deputies left the "new" Forza Italia) as well as within his area of influence (with some groups being drawn into the governmental majority). On the other hand, we witnessed the ascent of Salvini, who, in a relatively short period of time and banking on the fears engendered by mass migrations, the economic crisis, and the EU's failings, relaunched the Northern League and transformed it from a regional and secessionist party into a sort of "Ligue Nationale" modeled after the Front National of Marine Le Pen. Salvini certainly revealed leadership qualities and managed to dominate the media space of the center-right, so much so that by paraphrasing the expression of Edmondo Berselli, who had spoken of a rising "Forza Leghismo," he encouraged some observers to talk about a possible "Lega Forzismo." Yet the significant advances made by the Northern League appear to have leveled off, the party having failed to attract moderate voters with its overly radical statements and having failed to make any significant strides in the South, despite having created a new party label, "Together with Salvini," to this end (Diamanti 2015a, 2015e; Orsina 2015). However, if the center-right appears to have lost its identity for the better part of the year-and therefore to have lost its traditional electorate to the anti-systemic bids of the M5S or to have gambled on Renzi's reformist drive-it certainly still has a potential electorate that decided to sit on the fence while waiting for a new leader to emerge (Galli della Loggia 2015d; Ignazi 2015c; Panebianco 2015b).

Deep changes also characterized the Five Star Movement, which continued its process of normalization, increasingly resembling traditional parties. First, its electoral following solidified, obtaining remarkable results in the May elections-which was a non-obvious outcome, considering its non-existent territorial organization and lack of political personnel enjoying a clear local following (Tronconi 2015)-and the M5S accredited itself, according to many surveys, as the main alternative to the PD in the case of national political elections (D'Alimonte 2015e). The success of the M5S can be attributed to its capacity to draw followers across the electoral spectrum, mixing typically populist themes (anti-EU stances and anti-caste statements) with positions that allow it to overcome the left-right cleavage, for example, the promotion of a minimum wage for all citizens and various environmental 
initiatives (D’Alimonte 2015b; Ignazi 2015a; Pombeni 2015a). Moreover, the M5S has become the vehicle for a rising demand for change, especially among young people and students and particularly in the South. The other important novelty lies in the fact that the M5S has progressively detached itself from the tutelage of its charismatic leader Grillo (Bordignon and Ceccarini 2015; Conti and Memoli 2015). The decision to delete the name of Grillo from the party symbol and the creation in November 2014 of a new directoire (composed of five MPs charged with the task of constituting a reference point and forging a common political position in society and in Parliament) are no mere cosmetic decisions. Rather, they testify to the growing institutionalization of the movement (Ignazi 2015b), within which the main decisions are "no longer linked to the leader's charisma, but emerge from a process in which many leaders take part" (Diamanti 2015b).

Lastly, the Democratic Party lived through a particularly turbulent year, experiencing several divisions between majority and opposition and between center and periphery, so much so that some observers talked not by chance about the existence of (at least) two parties (Salvati 2015c). The progressive worsening of the relationship between the new secretariat and the historical leaders of the party had already escalated in 2014 following their "scrapping," yet internal conflicts grew even deeper in 2015 and led to the defection of a handful of first-rate national-level politicians. Faced with continuous attacks from the party's minority, Renzi never caved in and never appeared to seek appeasement, but instead looked for additional parliamentary support outside the traditional perimeter of the center-left (Pombeni 2015b). As Sergio Fabbrini and Marc Lazar (this volume) explain, the struggle related to the broad vision of the party. While for Renzi a leader should address primarily the voters and not the party members, for the PD minority (of which Bersani has been the main voice and reference point) the party has primacy over its leader (Calise 2015c). Moreover, while for Renzi being both party leader and prime minister is an advantage, for the minority of the party it has negative effects as it has led to a decline in party members, a loosening of the relationship between the party and its flanking organizations, and the growing detachment of center and periphery (Ignazi 2015d).

Paradigmatic in this respect was the discussion concerning a tax cut that Renzi announced in July at the Governing Council of the $\mathrm{PD}$, implicitly contradicting one of the leading principles of the left, which is still tied to a "tax-and-spend" vision of government as a way of redistributing income and promoting social equity (Ignazi 2015e; Panebianco 2015a). However, what undermined Renzi's leadership more than anything else was not the opposition within the Council, 
which he managed to overcome time and again, but the unassailable autonomy of the local level.

A particularly important case in point has been that of the city of Rome. The secretariat of the PD repeatedly criticized the actions of Rome's mayor, Ignazio Marino. After a series of publicity-wise devastating "incidents" (such as the "white strike" of the Rome traffic police, the extravagant funeral of a local Mafia boss, the polemic with Pope Francis on the occasion of his visit to the US, and a series of false fiscal receipts), the distancing of the PD secretariat from Rome's first citizen led to the resignation of the latter in October. However, it is not clear whether Renzi dismissed the weakness of the relationship between the central secretariat and local party structures as unimportant, or whether, as it rather seems, he simply decided to ignore it and to entertain a direct dialogue with the electorate, thus completely skipping the intermediation of the party structure (Piattoni 2016).

\section{A Year of Reforms}

The inner-party conflicts described above and the constraints exerted by the international context (on which there is more below) did not prevent the Renzi government from pursuing a reformist agenda. Indeed, during the course of the year, many of the reforms that had been promised upon assuming office were in fact passed. The government's activities have been characterized by a mix of measures on both the demand and the supply side. On the demand side, the executive enacted a series of short- to medium-term measures aimed at incentivizing consumption and investment and at eliminating some of the most glaring public inefficiencies. On the supply side, a few measures have been put into place aimed at redefining the political-administrative framework and at making governmental activity faster and bureaucratic activity more efficient - the latter seen as particularly penalizing for those who want to do business in Italy. The third element of this set of contextual policy measures, which aimed to reflate the economy, is the reform of civil legal procedures that was drafted in 2015 and should be completed in 2016. Although ambitious, this agenda can, according to some fairly critical commentators, be read as an attempt to garner electoral support rather than to actually boost domestic aggregate demand, an objective that we think should not be underestimated.

In terms of economic policy, the " 80 euro bonus," 2 already distributed to low-income families in 2014, was distributed again in 2015 and was accompanied by several measures in support of investment. These included a reduction of the tax on labor cost (IRAP), a tax cut 
on social security contributions that firms have to pay for workers hired on long-term contracts, the abolition of the tax on home ownership, and precautionary provisions to avoid a VAT increase in case of an excessive public deficit (Macroeconomicus 2015). Also the implementation decrees of the Jobs Act, which complete what according to Patrik Vesan (this volume) is the most daring reform ever of Italian labor law, were approved in 2015. The new implementation decrees affect a number of labor law chapters, providing for the introduction of the so-called open-ended contracts with increasing protection, ${ }^{3}$ the revision of the current scheme of unemployment compensation, and a series of interventions in the realm of active labor policies.

Moreover, according to Manuela Moschella (this volume), the new regulation of the banche popolari (people's banks) and banking foundations ${ }^{4}$ not only tried to solve some of the problems that affect the banking system-which suddenly surfaced at the end of the year on the occasion of the contested rescue of four banche popolari, one of them linked to the father of the minister of reforms, Maria Elena Boschi-but also intervened in a sector that is considered absolutely crucial for economic growth, given the role that these banks play in the financing of small and medium-sized enterprises. The most inadequate part of the executive's action has probably been in promoting the creation of new firms, which are hindered by a number of barriers to entry that protect existing and often inefficient firms. The ambitious reform bill of competition regulation drafted by the Ministry for Economic Development in February had to reckon with a high number of parliamentary amendments, many of them requested by parties belonging to the governmental majority itself. This slowed down the liberalization of many economic sectors that are fundamental for ensuring economic growth (Alesina and Giavazzi 2015b; Giavazzi 2015).

In the political-administrative field, in addition to the administrative reforms examined in the preceding paragraph, an important role was also played by the reform of the public administration itself. With respect to the past, when all hopes were pinned on the administrative autonomy and pluralism of the various governmental levels, the 2015 reform, as Fabrizio di Mascio and Alessandro Natalini (this volume) document, recentralized them and herded them back to unity. A further strategic axis of intervention was the effort to reduce public expenditures and to rejuvenate and requalify the administrative personnel, in particular, the new reform of public management, whose implementation, however, is not necessarily favorably assessed by public employees. Lastly, an important field of intervention concerns the refinement and implementation of the policies that aim to promote the simplification and computerization of administrative procedures and that strive 
to make public procedures and expenditures more transparent. While the reform of the public administration has been met with only moderate resistance-perhaps because the ideas that were eventually put into practice had been around for a long time and had already been partially introduced by previous executives - the reform of the schooling system treaded a rougher path. On the one hand, the executive singled out the stabilization of teachers on precarious job contracts, the introduction of merit-based hiring and promotion procedures, the opening up of the schooling system to stimuli deriving from the labor market, and the modernization of the teaching programs as the most innovative aspects of a reform aptly labeled the "Good School" reform. On the other hand, the parliamentary opposition, the PD minority, and large sectors of the trade unions contested the excessive power that, according to them, had been given to school principals, the method proposed to assess teachers' performances, the tax cuts granted to chartered private schools, the "school bonus," 5 and the insufficient attention given to combating economic inequalities (Ferrera 2015b; Galli della Loggia 2015c; Ricolfi 2015a; Urbinati 2015a). Gianluca Argentin and Carlo Barone (this volume) conclude that what was accomplished is in fact less than what had been announced, although more than what could be expected from a governmental coalition guided by a party that had clung to a fairly traditional view of the schooling system until very recently.

Overall, despite the favorable conjuncture caused by the collapse in the price of oil, the European Central Bank's expansionary monetary policy, and the flexibility granted by the EU, results have been lower than expected. On the one hand, gross domestic product has again entered positive territory ( 0.6 percent) following three years of recession; the overall unemployment rate has fallen to 11.4 percent and youth unemployment to 37.9 percent; and the Jobs Act has created new jobs and facilitated the transition from temporary to permanent contracts (Alesina and Giavazzi 2015d; EIU 2016; Ferrera 2015a). On the other hand, the tax burden has remained almost unchanged, so that some regions and municipalities have had to introduce new types of taxes to make up for the cuts introduced by the government (Ricolfi 2015d); reductions in government expenditure have been minimal and the public debt has remained at alarming levels (Alesina and Giavazzi 2015c; Cassese 2015a; Ricolfi 2015e); and the Mezzogiorno (the South of Italy) has virtually disappeared from the public agenda, or, better, rather than a comprehensive plan to effectively tackle the structural problems that have hampered its progress over the last decades, there has been only a change in discourse, now focused on the responsibilities of local leaders (Galli della Loggia 2015a; Ricolfi 2015c; Salvati 2015a). In short, "Renzinomics" has appeared strongly oriented to eliminate the 
structural weaknesses of the Italian regulatory context, but it can also be understood as an attempt to simultaneously maintain consensus at home and soften external constraints so as to buy the time necessary for economic recovery to kick in (Salvati 2015b).

As for the method, three important elements have characterized the action of the Renzi government: eclecticism, disintermediation, and centralization. First, Renzi has relied on different types of majority, depending on the decision to be made. Indeed, Renzi's mantra that his government would not take right-wing or left-wing measures but only "fair measures" was meant "to dilute the ideological dimension of its initiatives so as to move above and between the parties" (Ignazi 2015f). Such a fluid and ruthless strategy has surprised both the right and left. The right felt threatened by incursions on issues that they perceived as "theirs" (e.g., labor market flexibility, abolition of the tax on home ownership, reform of the bureaucracy) and therefore, to mark their presence, focused on ethical issues (in particular family and civil rights). The left, particularly within the PD, has been agitated by internal divisions that are not only or mainly tactical, but also "ontological" (Galli della Loggia 2015b). This dynamic and ruthless behavior and impatience with internal and external rituals differentiate Renzi from the minority of the PD, but they also highlight the Balkanization of the party into personalist factions and the reluctance of old leaders to hand control over to the younger generations. In this sense, those who have serious concerns regarding the formation of a "party of the nation"-that is, a post-ideological and, by definition, governmental party whose objective is that of maintaining power by making deals with different majorities or even with individual parliamentarians-interpret the governmental strategy with the help of categories that probably are no longer valid (Urbinati 2015b). Renzi's line of conduct is, in reality, similar to that prevailing in Scandinavian countries, which have been run by minority governments for decades and are used to building flexible majorities depending on the circumstance. Renzi has therefore sought to replace, by sheer will and with some imagination, the traditional view of a "transactional leader" with that of a "transformative leader" and to use the government to create his own electoral following rather than starting from a solid electoral basis in order to win the elections (Piattoni 2016).

Second, the Renzi government has rejected the mediation of representatives of various social categories, choosing instead to engage directly with citizens and public opinion. This so-called disintermediation (Pasquino 2015) has concerned trade unions, which on many issues had become the key shareholders of the PD and of previous governments (Addario and Fasano 2015). In its action, the Renzi 
government has been helped by a growing legitimacy crisis of trade unions, which have gradually lost the ability to go beyond the protection of their members and to deal with the problems faced by those who do not have a job (Diamanti 2015d; Ricolfi 2015b). This critical attitude, however, has not been extended to the corporations representing the productive and non-productive middle class, such as state employees (including magistrates and teachers) or the "lobby groups who do not want to hear about competition" (Alesina and Giavazzi 2015a; see also Cingolani 2015). To partly compensate for the weakening of the intermediary representative structures, the government has drawn on the knowledge and ideas of epistemic communities made of politicians and administrators, academics, and entrepreneurs.

Finally, the Renzi government has been characterized by a series of organizational choices that, on the one hand, have strengthened central structures, thus manifesting a strong disillusionment toward the experience of administrative and fiscal federalism, and, on the other hand, have centralized to the Council presidency coordination functions that were previously under the control of other entities. This trend, which began with the proposal to revise the second part of the Constitution, has found full application in the reform of the public administration, which granted to the Presidency of the Council of Ministers specific competences having to do with the analysis, definition, and evaluation of public policies and has assigned the direction of the offices directly linked to individual ministries to the Council presidency offices. Moreover, considering the weaknesses of senior civil servants, Renzi has recruited some technocrats to whom he has given specific tasks, thus outsourcing some important functions (Ainis 2015a; Cassese 2015b; Ventura 2015b). A strong role for the prime minister can be regarded as a novelty in Italy, the only possible exception being that of Bettino Craxi, who served from 1983 to 1987: in both the First and Second (phases of the) Republic, the most important decisions were made either within the leading party or by majority coalition summits (Diamanti 2015c). The executive has thus become the center of attention, also for the media, "not as political majority, but as decisionmaking leadership" (Calise 2015b). In addition, the way in which Renzi governs his team-at times allowing some loyal ministers to come to the fore, as with Maurizio Martina in the case of the Expo and Boschi in the case of institutional reforms, and sometimes preventing others from fully expressing their views, as happened with Stefania Giannini and Roberta Pinotti, respectively, during the reform of the school system and in view of a hypothetical military intervention in Libya-is more typical of an English cabinet or an American administration than a traditional Italian government. 


\section{A Difficult International Context}

There is no doubt that for many decisions in 2015, the European dimension has been even more important than the domestic one. The increasing Europeanization of public policies, however, has not been caused-as one might erroneously surmise from the political debate in Italy-only by the European Commission, but also, and particularly more recently, by a European Union that makes decisions following the intergovernmental method (Fabbrini 2015). To these external shocks, the Renzi government has reacted by putting forward a two-pronged strategy. On the one hand, it has sought to draw the attention of the other EU member states to issues that are crucial to Italy's national interest, such as the migration crisis and the sanctions against Russia. On the other hand, the Renzi government has suggested "changing the course" of Europe, criticizing the politics of austerity and the German ordo-liberal approach, with the not so hidden aim of achieving greater financial flexibility. However, the lack of well-defined proposals and a number of shifting positions have limited its capacity to influence the decision-making process of the EU. This was most notable in the case of the Greek crisis, which was initially seen as an opportunity to boost "the growth camp" but was then criticized due to the failure of the Tsipras government to respect the signed agreements, in strict observance of Germany's positions. It was finally viewed as a paradigmatic example of an excessive focus on economic parameters to the detriment of Europe's cultural mission. Although the year had begun with an attempt to restore relations following the tensions between Angela Merkel and Berlusconi, in the end, the year 2015 will be remembered for the harsh confrontation with Germany and for the repeated criticisms of the "Brussels bureaucrats," typical of right-wing and Euro-skeptic groups but less common among centerleft parties and governments.

The most emblematic case to assess the role of Italy in Europe is probably the migration crisis. In the first part of the year, the Renzi government, although contested at home by the opposition, kept rescuing migrants who were using the Mediterranean route to reach Europe. Its appeals to other member states not to leave Italy alone in managing what was considered "a European problem" were ignored until April, when the sinking of a ship in the Sicilian channel caused the death of more than 800 people. This led EU heads of state and government to increase the budget of the Triton operation to the level of the Mare Nostrum mission, although the issue of redistributing migrants across Europe was not resolved. Indeed, to the proposal of the president of the European Commission, Jean-Claude Juncker, to 
redistribute 24,000 refugees among all member states, Renzi replied that it was a "provocation" and that Italy would implement a "plan B"-which had the sole effect of increasing the number of refugees taken up by the EU to 40,000 in two years. In the second part of the year, the migration flow shifted toward the Balkans, with thousands of people attempting to go to northern Europe. These facts alleviated the pressure on Italy, but the announcement by Chancellor Merkel that Germany would accept all refugees from Syria seriously compromised the weak reception system in several European countries. After lengthy negotiations, in September the European Council, this time requested by Germany, imposed the compulsory relocation of 170,000 migrants (including 120,000 who had entered Italy and Greece). The broader question left unresolved, as Christopher Hill, Sara Silvestri, and Elif Cetin (this volume) explain, is the persistent difficulties that Italy faces to adapt to multiculturalism and to fully accept the presence of very different ethnic groups and religions within its territory.

More generally, on many international issues the Renzi government has played a marginal role. In fact, it has confirmed the impression that Italy is not very interested in taking part in collective action if doing so does not bring clear economic benefits or does not contribute to boosting its international profile-a kind of tactics that deserves the characterization made by Vittorio Emanuele Parsi (this volume) as "moving without the ball." For example, the response to terrorism has been timid. To the French government's requests for support after the tragic attacks in November (following those in January), Renzi replied with mere declarations of solidarity, arguing that the bombing of ISIS/ Daesh strongholds was not the best way to end the civil war in Syria; instead, Italy would strengthen its presence in other dangerous situations (Parsi 2015a; Silvestri 2015). As for the Libyan crisis, the Renzi government also sent conflicting messages. Against the declarations of Foreign Minister Paolo Gentiloni and Defense Minister Pinotti, which already in February seemed to suggest imminent military action, Renzi proposed a more prudent attitude-which, for Parsi, could be regarded as "a scouting effort to uncover potential opposition." Italy assumed a prominent role only in December, when, together with the US, it convened a peace conference in Rome offering the international community's backing to any future national executive that managed to keep together the two warring Libyan factions-and indirectly advancing Italy's legitimate claim to coordinate any peace mission in this country (Parsi 2015b). Finally, the unsuccessful attempt to break the isolation of Russia confirms that, irrespective of which type of government is in power, Italy has been constantly seeking to play a bridging role between Moscow and the rest of the world. The aim has been not 
only that of promoting its own commercial interests-certainly in the energy sector but also in the agricultural sector, both of which were strongly penalized by the EU's sanctions-but also that of cooperating with Russia in finding a solution to the conflict in Syria (Carteny 2015).

The role claimed in the Libyan crisis and the attempt to soften the attitude of the international community toward Russia can be seen as strategies for intervening directly in areas where Italy has significant economic interests at stake. Indeed, one of the cornerstones of Renzi's foreign policy has been his activism in finding new markets for Italian companies and in attracting foreign investment to Italy. This is the meaning that we can attribute to the various visits made by the prime minister to Asia, Africa, and Latin America, as well as some European capitals. Although certainly inspired by a genuine desire to galvanize the national economy, the Renzi government has almost exclusively relied on the capacity of the Italian entrepreneurial class and has focused mostly on those areas that are part of the Italian "productive DNA" (e.g., food, fashion, arts). Nevertheless, the Italian economy has struggled to take off, not least because its economic structure is based on small and medium-sized enterprises, which lack the necessary resources to act globally and are still unable to work together (Colombo and Magri 2016).

What contributed most in 2015 to increase the prestige of Italy internationally was probably the Universal Exposition (Expo 2015), which was held in Milan between May and October. This event not only reconfirmed Italy's leadership role in the agro-food sector, but also provided the occasion to host several heads of state and government, thus launching a sort of "gourmet diplomacy." Renata Lizzi (this volume) notes that despite a number of scandals and delays, the final outcome was very positive, thanks to the effective organization of the event, a renewed civic spirit, and an excellent network of diplomatic relations promoted by the prime minister and by anyone who, within the central government and the various local authorities, entertained relations with foreign countries.

\section{Conclusion}

At the traditional end-of-year press conference when the president of the Council of Ministers gives an account of the government's activities over the previous 12 months, ${ }^{6}$ Renzi stated that he would tie his future in politics to the constitutional referendum scheduled for October 2016. This announcement confirms, once again, that the prime minister relies more on his ability to engage the voters directly with 
his "changing course" narrative than on seeking consensus within his own party and the governmental majority, which had locked previous governments into exhausting negotiations and forced them to accept often unsatisfactory compromises. During the press conference, Renzi gave an account of the many completed reforms (labor market, school system, public administration, cooperative banks and banking foundations, electoral law, radio and television system) and of others that were initiated during the year (justice, civil partnerships, revision of the Constitution) amid many polemics and difficulties. Renzi has been able to gain room to maneuver between a numerically significant but internally divided opposition and an internally divided but numerically solid majority and has thus been able to complete a series of reforms where many previous governments had failed. The relatively calm waters on which he managed to sail are more the result of his navigational skills than of the lack of storms. Yet all the while, increasingly threatening clouds continue to accumulate and disturb the helmsman.

On the internal front, the first problem that Renzi inherited was a composite and turbulent majority, despite its being a grand coalition. This same problem had affected the performance of previous governments led by Mario Monti and Enrico Letta. The Nazarene pact, which was seen as a potential solution to this problem, ended in early 2015 on the occasion of the election of the president of the Republic. Those who had welcomed the appointment of Mattarella as a way to reunite the PD, which had faced significant internal clashes over the alliance with Berlusconi, were disappointed. However, Renzi benefited, and he may continue to do so in the future, from a weak center-right camp and from persistent doubts over the capability of the Five Star Movement to govern-two arguments that might make the PD almost invulnerable and may determine the outcome of the next general elections. This state of affairs increases the opportunistic behavior of parties and individual politicians who try to bandwagon and seriously questions the return to alternation in power, thus crystallizing a pattern of competition that, also thanks to the adoption of a new electoral law, would lead to the advent of a system with a dominant party surrounded by irreconcilable and irresponsible oppositions. If this brings us, in some ways, back to the First (phase of the) Republic, it does however strengthen the position of the prime minister at the expense of the president of the Republic, but also other members of the government-an end result that may pave the way to the Third (phase of the) Republic.

Finally, the international front has confirmed some of the weaknesses of the Italian government, notably, in the management of migration flows, in the difficult transition in Libya, and in leading a coalition 
of EU member states supporting the view that austerity in times of recession only aggravates the economic problems of weaker countries and ultimately of all countries. In foreign policy, the achievements of the Renzi government have not been very different from those of its predecessors. Indeed, Italy is often an awkward and ineffective international actor: it gets involved late and in the wrong arenas and does not manage to shape the European agenda due to its weak credibility in regard to keeping its commitments. This may be a consequence of the fact that Italy adapts to European rules only when they are imposed under the threat of a penalty-after all, the concept of vincolo esterno (external constraint) was first applied to the Italian case-and does not attend with sufficient diligence the forums at which crucial policies are made. In the end, the ambitious attempt made by Renzi to "change the course of Europe" did not have the desired effect. If his assertiveness is seen as an asset in Italy, it is not seen so in Europe, where achieving results requires a clear strategy and the patience to engage constructively with national governments and supra-national institutions.

Maurizio Carbone is Professor of International Relations and Development and Jean Monnet Professor of EU External Policies at the University of Glasgow.

Simona Piattoni is Professor of Political Science at the University of Trento.

\section{Notes}

1. The Nazarene pact-so called because it was sealed during a meeting in the central offices of the Democratic Party located in via del Nazarenoentailed an agreement between the two party leaders on the main institutional and constitutional reforms, including the election of the president of the Republic.

2. The "80 euro bonus" is, technically, a tax break granted to families with overall incomes below a certain threshold. It is aimed at boosting sagging consumption levels and at soothing the plight of poorer households.

3. This is a new form of contract that grants workers increasing guarantees the longer the term of their contract.

4. For a definition of both, see Moschella (this volume).

5. A "school bonus" of 500 euros is granted to all teachers working at all levels of primary and secondary education. It can be used to buy books, computers, and computer programs or to pay for courses of their choice. 
6. For a full picture of the events of the year, see the chronology prepared by Rinaldo Vignati.

\section{References}

Addario, N., and L. M. Fasano. 2015. "La vera innovazione è politica.” Il Mulino 64, no. 1: 63-68.

Ainis, M. 2015a. "Il potere diretto del leader." Corriere della Sera, 7 August.

Ainis, M. 2015b. "Troppi silenzi sull'astensione." Corriere della Sera, 18 June.

Alesina, A., and F. Giavazzi. 2015a. "Ascoltare i cittadini non le lobby.” Corriere della Sera, 4 August.

Alesina, A., and F. Giavazzi. 2015b. "Lo scarso coraggio di Renzi." Corriere della Sera, 1 March.

Alesina, A., and F. Giavazzi. 2015c. "Lo slancio perduto del premier." Corriere della Sera, 12 April.

Alesina, A., and F. Giavazzi. 2015d. "Una legge di stabilità che non promuove la crescita." Corriere della Sera, 22 October.

Bordignon, F., and L. Ceccarini. 2015. "The Five-Star Movement: A Hybrid Actor in the Net of State Institutions." Journal of Modern Italian Studies 20, no. 4: 454-473.

Calise, M. 2015a. "La democrazia del leader.” Il Mulino 64, no. 2: 203-212.

Calise, M. 2015b. "La premiership che svuota il bipolarismo." Il Mattino, 3 October.

Calise, M. 2015c. "Più la sinistra assedia più Renzi va all'attacco." Il Mattino, 10 August.

Carbone, M. 2015. "Beyond the Telemacus Complex: Course, Discourses and the 2014 Italian Presidency of the Council of the European Union." Journal of Common Market Studies 53, S1: 83-92.

Carteny, A. 2015. "Renzi a Mosca, per il rilancio del ruolo italiano." AffarInternazionali, 9 March.

Cassese, S. 2015a. "La via virtuosa dei tagli alla spesa.” Il Sole 24 Ore, 13 September.

Cassese, S. 2015b. "Renzi a Palazzo Chigi: I due volti di una leadership." Corriere della Sera, 22 July.

Cingolani, S. 2015. "Renzinomics al microscopio.” Il Foglio, 11 November.

Colombo, A., and P. Magri, eds. 2016. ISPI Rapporto 2016: Le nuove crepe della governance mondiale, scenari globali e l'Italia. Milan: ISPI.

Conti, N., and V. Memoli. 2015. "The Emergence of a New Party in the Italian Party System: Rise and Fortunes of the Five Star Movement." West European Politics 38, no. 3: 516-534.

D’Alimonte, R. 2015a. "In 10 anni l'affluenza alla regionali ha perso 18 punti." Il Sole 24 Ore, 3 June.

D’Alimonte, R. 2015b. “M5s 'trasversale,' voti da tutti i partiti.” Il Sole 24 Ore, 20 December.

D’Alimonte, R. 2015c. “The New Italian Electoral System: Majority-Assuring but Minority-Friendly." Contemporary Italian Politics 7, no. 3: 286-292. 
D’Alimonte, R. 2015d. “Renzi ha violato il metodo del Nazareno ma il patto può resistere." Il Sole 24 Ore, 1 February.

D’Alimonte, R. 2015e. "Sui nodi italiani partiti poco credibili." Il Sole 24 Ore, 29 November.

Diamanti, I. 2015a. "Il forzaleghismo al test ballottaggio la sfida democratici in 4 punti." La Repubblica, 9 November.

Diamanti, I. 2015b. "La mutazione genetica del Movimento di Grillo: Di Maio ora è il leader. 'Con lui governeremo.”' La Repubblica, 30 November.

Diamanti, I. 2015c. "La post-democrazia fondata sul premier.” La Repubblica, 3 August.

Diamanti, I. 2015d. "La solitudine del sindacato.” La Repubblica, 31 August.

Diamanti, I. 2015e. "Renzi, leader senza partito lui sale ma il Pd scende M5S ancora in crescita FI controsorpassa la Lega." La Repubblica, 17 October.

EIU (Economist Intelligence Unit). 2016. “Country Report: Italy.” February. http://country.eiu.com/italy.

Fabbrini, S. 2015. “Governi stabili per contare nella Ue.” Il Sole 24 Ore, 1 October.

Ferrera, M. 2015a. "Gli errori sul lavoro dei giovani.” Corriere della Sera, 25 March.

Ferrera, M. 2015b. "La scuola non è solo una legge.” Corriere della Sera, 20 May.

Galli della Loggia, E. 2015a. "Il Mezzogiorno dimenticato e lo scatto necessario." Corriere della Sera, 21 December.

Galli della Loggia, E. 2015b. "Il partito che Renzi non ha." Corriere della Sera, 21 October.

Galli della Loggia, E. 2015c. "La visione che manca alla buona scuola.” Corriere della Sera, 8 March.

Galli della Loggia, E. 2015d. "Se la sinistra attua politiche di destra." Corriere della Sera, 10 February.

Giavazzi, F. 2015. "Steccati da demolire (subito)." Corriere della Sera,

9 November.

Ignazi, P. 2015a. "Il male dei partiti e il populismo.” La Repubblica,

23 December.

Ignazi, P. 2015b. “Isolato da tutti così prospera 5 Stelle.” L’Espresso, 25 November.

Ignazi, P. 2015c. "La destra non ha voti ma ha un popolo.” L'Espresso, 10 September.

Ignazi, P. 2015d. "La responsabilità del partito democratico.” La Repubblica, 2 July.

Ignazi, P. 2015e. "Le anomalie di Renzi e del Pd.” La Repubblica, 1 August. Ignazi, P. 2015f. “Premier giovane idee vecchie.” L'Espresso, 12 November. Macroeconomicus. 2015. "Renzinomics.” Il Mulino 64, no. 2: 213-222.

Orsina, G. 2015. “I tre vantaggi del leader della lega.” La Stampa, 9 November.

Panebianco, A. 2015a. "I riflessi condizionati sulle tasse da ridurre." Corriere della Sera, 28 August.

Panebianco, A. 2015b. "Lo sgarbo e il futuro del patto." Corriere della Sera, 2 February. 
Parsi, V. E. 2015a. “E Renzi disse: Armiamoci e partite.” Panorama, 10 December.

Parsi, V. E. 2015b. “Operazione Libia perché Roma rischia grosso.” Panorama, 22 December.

Pasquino, G. 2015. “La leadership della rottamazione.” Il Mulino 64, no. 2: 254-219.

Piattoni, S. 2016. "Lo stile di policy del governo Renzi.” Rivista Italiana di Politiche Pubbliche 11, no. 1: 5-22.

Pombeni, P. 2015a. “Il partito 'anti' alla prova delle decisioni politiche.” Il Sole 24 Ore, 2 June.

Pombeni, P. 2015b. "Rischi e paradossi del confronto interno al Pd." Il Sole 24 Ore, 4 August.

Revelli, R. 2015. Dentro e contro: Quando il populismo è di governo. RomeBari: Laterza.

Ricolfi, L. 2015a. "Il pasticciaccio brutto di una scuola scadente.” Panorama, 3 June.

Ricolfi, L. 2015b. “Il sindacato e quel prestigio perduto.” Il Sole 24 Ore, 11 October.

Ricolfi, L. 2015c. “Mezzogiorno come la Grecia?” Il Sole 24 Ore, 9 August.

Ricolfi, L. 2015d. "Non pagheremo meno tasse e vi spiego perché.” Panorama, 22 October.

Ricolfi, L. 2015e. “Senza tagli di spesa la rivoluzione è a metà.” Il Sole 24 Ore, 18 October.

Salvati, M. 2015a. "Attuare le riforme al sud è più difficile." Corriere della Sera, 7 August.

Salvati, M. 2015b. "I tre pilastri (più uno) della Renzinomics tra riforme e consenso.” Corriere della Sera, 9 January.

Salvati, M. 2015c. "Renzi, Stick to Your Guns.” Il Mulino 64, no. 5: 787-795.

Silvestri, S. 2015. "Se l'Italia bombarda il Califfo.” AffarInternazionali, 8 October.

Tronconi, F., ed. 2015. Beppe Grillo’s Five Star Movement: Organisation, Communication and Ideology. Aldershot: Ashgate.

Urbinati, N. 2015a. “Che 'Ditta' è mai questa? Il Pd e la pessima riforma della scuola." Left, 4 July.

Urbinati, N. 2015b. "Ma quale nazione: È il partito destrinista.” Left, 19 September.

Ventura, S. 2015a. Renzi \& Co.: Il racconto dell'era nuova. Soveria Mannelli: Rubbettino.

Ventura, S. 2015b. “Un leader, due poltrone.” Il Resto del Carlino, 28 November. 